\title{
PERBANDINGAN KEMAMPUAN PEMAHAMAN KONSEP MATEMATIS MELALUI MODEL PEMBELAJARAN TAKE AND GIVE DAN MODEL PEMBELAJARAN PROBLEM BASED LEARNING ( PBL ) PADA SISWA KELAS VIII SMP NEGERI 11 KOTA JAMBI
}

\author{
Desi Susanti ${ }^{1}$, Hasan Basri $^{2}$, Relawati ${ }^{3}$ \\ Program Studi Pendidikan Matematika, FKIP, Universitas Batanghari ${ }^{1,2,3}$ \\ J1. Slamet Riyadi No.1 Broni Jambi \\ e-mail: darasuciati24@gmail.com
}

\begin{abstract}
ABSTRAK
Penelitian ini bertujuan untuk mengetahui kemampuan pemahaman konsep matematis siswa yang dibelajarkan melalui model pembelajaran Problem Based Learning (PBL ) lebih tinggi dari pada kemampuan pemahaman konsep matematis siswa dengan model pembelajaran Take and Give pada kelas VIII SMPN 11 Kota Jambi tahun ajaran 2017/2018 yang berjumlah 105 siswa Penelitian ini merupakan penelitian eksperimen. Populasi dalam penelitian ini adalah siswa kelas VII SMP N 11 Kota Jambi Tahun Ajaran 2018/2019. Pengambilan sampel menggunakan teknik random sampling dan yang terambil adalah kelas VIII A dan VIII C, dimana kedua kelas sampel ini diberikan perlakuan berbeda. Penelitian ini bertujuan untuk mengetahui perbedaan rata-rata hasil post-test siswa yang menerapkan model pembelajaran Take and Give dengan model pembelajaran Problem based Learning pada pokok bahasan Aljabar. Dari hasil penelitian yang dilakukan skor rata-rata untuk kelas eksperimen adalah 75,81 dengan simpangan baku 12,02 dan kelas kontrol rata-ratanya 69 dengan simpangan baku 10,13. Serta dari hasil uji hipotesisnya diperoleh t_hitung yaitu 2,18 dan t tabel yaitu 1,68 pada taraf nyata $\alpha$ yaitu 0,05 . Dari hasil perhitungan itu terlihat bahwa t_hitung lebih besar dari $\mathrm{t}$ tabel maka $\mathrm{H}_{\mathrm{o}}$ ditolak dan $\mathrm{H}_{1}$ diterima. Berdasarkan hasil akhir dapat disimpulkan bahwa model pembelajaran Problem Based Learning (PBL) lebih baik untuk meningkatkan kemampuan pemahaman konsep matematis siswa daripada model pembelajaran Take and Give siswa kelas kelas VIII SMN 11 Kota Jambi.
\end{abstract}

Kata kunci :

Pemahaman Konsep Matematis ; Model Pembelajaran Problem Based Learning (PBL); Model Pembelajaran Take and Give

\begin{abstract}
This study aims to determine the ability to understand mathematical concepts of students who are taught through the Problem Based Learning (PBL) learning model is higher than the ability to understand mathematical concepts of students with Take and Give learning models in class VIII SMPN 11 Jambi City academic year 2017/2018 which amounted to 105 students This research is an experimental study. The population in this study were students of class VII SMP N 11 Jambi City Academic Year 2018/2019. Sampling uses a random sampling technique and what is taken is class VIII A and VIII C, where both classes of sample are given different treatment. This study aims to determine the differences in the average post-test results of students who apply the Take and Give learning model with the Problem based Learning learning model on the subject of Algebra. From the results of the study the average score for the experimental class was 75.81 with a standard deviation of 12.02 and an average control class of 69 with a standard deviation of 10.13. As well as from the results of the hypothesis test, t_count is 2.18 and t table is 1.68 at the $\alpha$ level of 0.05. From the results of the calculation it appears that t_count is greater than ttable then $\mathrm{Ho}$ is rejected and $\mathrm{HI}$ is accepted. Based on the final results it can be concluded that the Problem Based Learning (PBL) learning model is better for improving students' understanding of mathematical concept skills than the Take and Give learning model of class VIII students of SMN 11 Jambi City.
\end{abstract}

Keywords:

Understanding of Mathematical Concepts; Problem Based Learning (PBL) Learning Model; Take and Give Learning Model 
$\pi$ (Phi)

\section{PENDAHULUAN}

Matematika merupakan salah satu ilmu dasar yang mempunyai peranan penting. Banyaknya kegunaan dari matematika sehari-hari merupakan salah satu alasan mengapa matematika merupakan pelajaran sekolah yang dipandang penting dan dipelajari oleh peserta didik di semua tingkat pendidikan dan pelajaran matematika juga merupakan salah satu sarana dalam membentuk siswa untuk berpikir secara alamiah (Fitriani, 2015)

Mengingat pentingnya peranan matematika, maka keberhasilan belajar matematika setiap sekolah perlu mendapatkan perhatian yang serius. Keberhasilan dalam mempelajari matematika dapat dilihat dari penguasaan siswa terhadap pemahaman konsep, pemecahan masalah, dan komunikasi.

Pemahaman konsep dalam matematika merupakan kemampuan dasar yang harus dimiliki siswa dalam proses belajar mengajar. Pemahaman konsep juga merupakan dasar untuk melanjutkan ke materi yang lainnya. Apabila seorang siswa tidak memahami konsep dasar dalam proses pembelajaran matematika, maka untuk tahap selanjutnya akan lebih sulit. Sebab matematika merupakan mata pelajaran yang saling terkait satu sama yang lainnya dan tidak dapat dipisahpisahkan serta mengikuti urutan tertentu, hal ini berarti konsep yang satu berkaitan dengan konsep yang lain. Oleh sebab itu, salah satu masalah yang penting diperhatikan dalam proses pembelajaran matematika ialah konsep yang akan ditanamkan pada siswa.

Model pembelajaran Problem Based Learning (PBL) dapat membantu mengembangkan kemampuan pemahaman konsep matematis yang terlihat dari 7 aspek yang terdapat pada model ini yaitu: 1) mengklarifikasi istilah dan konsep yang belum jelas; 2) merumuskan masalah 3) menganalisis masalah 4) menata gagasan secara sistematis; 5) memformulasikan tujuan pembelajaran; 6) mencari informasi tambahan dari sumber lain; 7) mensintesis ( menggabungkan ) dan menguji informasi baru dan membuat laporan.

Pembelajaran dengan model Problem Based Learning (PBL) siswa juga disituasikan untuk belajar berkelompok dalam menyelesaikan masalah-masalah yang ada. Kelompok tersebut terdiri dari siswa yang heterogen. Situasi belajar berkelompok yang heterogen ini dapat menonjolkan interaksi dalam kelompok seperti tanya jawab, tukar pendapat, dan debat antar siswa. Selain dari itu, belajar berkelompok mampu membuat siswa menerima siswa lain yang berkemampuan latar belakang yang berbeda.Judul penelitian ini adalah perbandingan kemampuan pemahaman konsep matematis melalui model pembelajaran Problem Based Learning (PBL) dan model pembelajaran Take and Give pada siswa kelas VIII SMP.

\section{METODE PENELITIAN}

Jenis penelitian yang digunakan dalam penelitian ini merupakan quasi eksperimen. Menurut (Sugiyono, 2015) quasi eksperimen dapat diartikan sebagai metode penelitian yang digunakan untuk mencari pengaruh perlakuan tertentu terhadap yang lain dalam kondisi yang terkendalikan.

Penelitian ini dilakukan terhadap dua kelas,yaitu kelas eksperimen dan kelas kontrol. Pada kelas eksperimen dilakukan model pembelajaran Problem Based Learning (PBL) dan pada kelas kontrol menggunakan model pembelajaran Take and Give.

Dalam penelitian ini yang akan dijadikan populasi adalah seluruh siswa kelas VIII SMP Negeri 11 Kota Jambi yang terdiri dari 6 kelas. Sampel yang digunakan sebanyak dua kelompok sampel yaitu kelompok eksperimen dan kelompok kontrol. Kelompok eksperimen merupakan kelas yang diajarakan dengan model Problem Based Learning dan kelas kontrol merupakan kelas yang diajarkan dengan model pembelajaran Take and Give. pengambilan sampel tersebut menggunakan 


\section{$\pi$ (Phi)}

teknik random sampling, yaitu pengambilan smple secara acak dari populasi yang berdistribusi normal tanpa memperhatikan strata yang ada dalam populasi itu (Sugiyono,2015).

\section{HASIL DAN PEMBAHASAN}

Berdasarkan hasil posttest pada pokok bahasan SPLDV, kemampuan pemahaman konsep matematis kelas eksperimen yang diajar melalui model pembelajaran Take and Give memperoleh rata-rata 75,81 dengan simpangan baku 12,02. Sedangkan kelas kontrol yang diajar melalui model pembelajaran Problem Based Learning ( PBL) memperoleh rata-rata 69 dan simpangan baku 10,13. Sehingga dapat disimpulkan bahwa kelas eksperimen dan kelas kontrol berdistribusi normal. uji homogenitas Posstest meghasilakn Fhitung sebesar 1,41 dan Ftabel sebesar 1,96. Oleh karena nilai Ftabel lebih kecil dari pada Ftabel Sehingga dapat disimpulkan bahwa kelas eksperimen dan kelas control mempunyai varians yang homogen. nilai thitung $=2,21$ lebih besar dari ttabel $=1,68$ berarti H0 ditolak atau kemampuan pemahaman konsep matematis siswa yang dibelajarkan dengan model pembelajaran Problem Based Learning (PBL) lebih tinggi dari pada kemampuan pemahaman konsep matematis siswa yang dibelajarkan dengan model pembelajaran Take and Give.

Pembelajaran menggunakan model Problem Based Learning (PBL) dan model pembelajaran Take and Give pada kelas eksperimen dan kelas kontrol. Pada proses pembelajaran di kelas eksperimen yang menggunakan model pembelajaran Problem Based Learning (PBL) dilakukan dengan membentuk beberapa kelompok yang terdiri dari 4 orang siswa. Setelah berkelompok mereka akan bersama-sama mengerjakan lembar kerja siswa (LKS) dan pada langkah introducing the new concept yang melatih kemampuan pemahaman kosnep matematis siswa, serta metakognitive questioning yang mengkonstruksi pengetahuan siswa. Pada awal pertemuan siswa mengalami beberapa kesulitan dalam mengerjakan LKS.

Namun, dengan bimbingan guru mereka dapat memahaminya. Hal ini dikarenakan siswa belum terbiasa dengan proses pembelajaran dimana mereka dituntut untuk dapat memahami sendiri konsep matematika melalui permasalahan yang diberikan. Setelah menyelesaikan pengerjaan LKS salah satu dari perwakilan kelompok diminta untuk menjelaskan hasil diskusi kepada teman-temannya dan teman lain memberikan tanggapan. Adanya tahap siswa mempresentasikan hasil kerjanya dan siswa lain memberikan tanggapan terhadap hasil pekerjaan temannya dapat melatih siswa untuk mengekspresikan ide-ide matematikanya. Hal ini sebagaimana yang dikemukakan oleh Defitriani (2015) bahwa dengan adanya diskusi kelompok, akan meningkatkan kognitif siswa hingga pembelajaran menjadi bermakna.

Pada proses pembelajaran di kelas kontrol yang menggunakan model pembelajaran Take and give proses pembelajaran berjalan seperti biasanya. Pada kelas kontrol guru terlebih dahulu menjelaskan materi dan konsep matematika. Selanjutnya siswa diminta untuk mengerjakan latihan mandiri untuk melihat sampai sejauh mana pemahaman siswa tersebut. Selain itu, berdasarkan nilai posttest diketahui bahwa kemampuan pemahaman konsep matematis siswa di kelas ekperimen selalu lebih tinggi dibandingkan kelas kontrol. Aktivitas siswa pada tahap introducing the new concept, metacognitive questioning, practicing dan obtaining mastery memiliki peran besar dalam pengaruh yang diberikan, hal ini dikarenakan pada tahap inilah siswa mengorganisasikan ide-ide nya untuk memahami materi sehingga memicu berpikir kritis pada siswa dan kemampuan komunikasi siswa dapat lebih dikembangkan. Sementara pada penerapan 


\section{$\pi$ (Phi)}

pembelajaran langsung, siswa hanya menerima informasi ataupun materi yang diberikan oleh guru.

\section{SIMPULAN DAN SARAN}

Rata-rata kemampuan pemahaman konsep matematis siswa pada kelas eksperimen yang diajarkan dengan menerapkan model pembelajaran Problem based learning ( PBL ) pada pokok bahasan SPLDV memperoleh nilai rata-rata 75,81 dengan simpangan baku 12,02. Rata-rata kemampuan pemahaman konsep matematis siswa pada kelas kontrol yang diajarkan dengan menerapkan model pembelajaran Take and give pada pokok bahasan SPLDV memperoleh nilai rata-rata 69 dengan simpangan baku 10,13.Dari hasil perhitungan diperoleh thitung yaitu 2,21 lebih besar dari ttabel yaitu 1,67 maka Ho ditolak. Jadi dapat disimpulkan bahwa model pembelajaran Problem Based Learning lebih baik untuk meningkatkan kemampuan pemahaman konsep matematis siswa daripada siswa yang diajarkan dengan model pembelajaran Take and Give.

\section{DAFTAR PUSTAKA}

Defitriani, E. (2015). Penerapan Pendekatan Differentiated Instruction (DI) Untuk Meningkatkan Kemampuan Koneksi dan Disposisi Matematis Siswa SMP. Tesis. Bandung: Program Pascasarjana UPI Bandung.

Fitriani, S. (2015). Perbandingan Hasil Belajar Matematika Siswa Dengan Menerapkan Strategi Pembelajaran Aktif Tipe Practice-Rehearsal Pairs dan Action Learning di Kelas VIII SMP Negeri 16 Kota Jambi: Ekotrans.15 (1), 91-102.

Sugiyono. 2012. Motode Penelitian Kuantitatif, Kualitatif, dan R\&D. Bandung: Alfabeta 